\title{
Extreme events (flood \& drought) and food security measures in the aspects of local perception
}

\author{
M. A. Rakib ${ }^{1, ~ *, ~ M . ~ S . ~ A k t e r ², ~ M . ~ B . ~ H o s s a i n ~}{ }^{3}$ \\ ${ }^{1}$ Department of Disaster Management, Begum Rokeya University, Rangpur, Bangladesh \\ ${ }^{2}$ Department of Statistics, Jahangirnagar University, Savar, Dhaka, Bangladesh \\ ${ }^{3}$ Department of Zoology, Rangpur Government College, Rangpur, Bangladesh \\ Email address: \\ rakibmamun_ju@yahoo.com (M. A. Rakib), abdur.rakib84@yahoo.com (M. A. Rakib)
}

To cite this article:

M. A. Rakib, M. S. Akter, M. B. Hossain. Extreme Events (Flood \& Drought) and Food Security Measures in the Aspects of Local

Perception. American Journal of Agriculture and Forestry. Vol. 2, No. 4, 2014, pp. 183-191. doi: 10.11648/j.ajaf.20140204.21

\begin{abstract}
Natural hazards and its negative consequences on agricultural activities revealed that, crop production rate is gradually dwindled. Climatic hazards were identified as a critical factor, whereas it may emerge a barrier to get better crop yielding options. Local perception on natural hazards directly coincided with the observational factors. A number of people were observed food insecure during flooding and drought hazards in case of improper cultivation and marketing approach. Now-a-days food security is a great challenge in rural and disaster prone area, which is indicated to local impacts, occupational stress and livelihood diversification. In addition, a number of climatic factors were found to be significantly negative correlation with the crop production rate. However, compartmental research would be very helpful to build up coping capacity, adaptation and recovery on time measures along with the proper action.
\end{abstract}

Keywords: Extreme Events, Food Security, Agriculture and Local Perception

\section{Introduction}

Natural hazard is an emerging issue whereas it may pose potential threat to survive in an ordinary livelihood pattern. Most of the peoples are directly or indirectly being victimized due to uncertain natural hazards. Natural hazards (flood and drought) frequency is directly influenced by climate change [1]. It is a critical point to find out the real cause of hazards and make out the controlling outline as a mitigation approach. In any situational case, the social development depends on sustainable managerial capacity and knowledge empowerment at the regional and global scale. But the overall performance helps to reduce livelihood crisis and food insecurity. Food security, where does it ensure all access of safe food and nutrition lead to active life [2]. Food insecurity indicates to scarcity and/or unavailability of nutritionally acceptable adequate safe food leads to healthy life [3]. In the developing countries, most of the peoples are sufferings from serious health problem due to food insecurity [4].

The developed and developing country is encountered with several types of natural and human induced hazards.
But most of the developing country is faced with worst condition due to unavailability of resource and lack of mitigation technique. Nevertheless, Bangladesh is a hazard prone country which is located at the geographically hazards settings area. A number of hazards like flood, tornado, drought, cyclone and etc hits every year in a cyclic order. Gradually increasing drought, flood, salinity and sea level rise, its frequency and intensity has been negatively impacted on natural resource along with human system and ecology [5]. The river bank erosion, flood, drought, cyclone, salinity intrusion and tornados are a common natural event which is frequently occurred in Bangladesh [6]. But its frequency and magnitude directly emphasize on local people and increase vulnerability. Consecutively, it is negatively attributed to worsen socio-economic condition and social crisis. In addition, socioeconomic crisis has been coincided with the uncertain natural and anthropogenic stress in a specific area and cause. However, food security and insecurity directly make a linkage between livelihood pattern and its availability along with household activities and resource availability. But it varies from place to place which is depends on development treads and its continuity.

Sometimes social crisis indicate to the socioeconomic 
imbalance and food scarcity. Food security deals with food access (including income and ability to buying food in relation to marketing parameter), availability (depends on crop productivity along with food waste) and its proper utilization (containing nutritional quality and safety) [7, 8]. It varies from rural to urban area because of financial activities and source. However, agriculture based economy and development goals one of the better way to secure food in the rural area. But in some cases it is impaired and/or broken-down due to the seasonal climatic uncertainty and lack of consciousness. Consecutively, natural hazard and its negative consequences act as a key factor to split the economical trends and enhancing poverty. The aim of the study is to investigate the real setting of natural hazards occurring area and the local perception with special reference to fulfillment of daily dietary intake. It also deals with regional feature along with traditional expertise of the local people in relation to adaptation at the time of crisis.

\subsection{Food Security and Climate Change}

Bangladesh as an agro-economy depended country, its food comes from agricultural sector but agriculture activities depends on climatic variables such as temperature, precipitation, pressure, wind, humidity and etc. Consecutively, Agricultural production rate gradually decreases due to imbalance condition of climate and food becomes insecure. Food security depends on regional natural activities and its variation, such as - natural hazards, climate changing pattern, distribution and quality of agricultural land, education, employment opportunities and food habits. Climatic variables and its changing pattern are expected negatively attribute to crop growth and take into further challenge to fulfill local and household food security [9-13]. Extreme events such as droughts, floods, cyclones etc. causes loss of crop yield that affects specially in food security and agricultural livelihood. As a result, agriculture dependent people do not get enough facilities of fundamental needs income, food, safe water, habitation, proper education and etc. and they are diverted themselves into other occupations for the better living standard. Climate change is directly focused to food security and social livelihood pattern. In summer season, temperature remains so high, it is one of the main causes of drought occurring. However, the soil becomes dry and does not able to make availability of necessary nutrients and reduces soil fertility. As a result, agricultural production profit is less than farmer expenditure. A number of factors such as low soil fertility, trade relationship, feeble infrastructure and institution, population growth and future climatic variation act as a key factor to remove poverty and achieve food security [14]. In addition, yearly drought damages enormous amount of crops, crop lands and fail to reach the target production. Mainly in char area like "chilmari" in Kurigram district of Bangladesh, agriculture dependent people lost their crop lands because of river bank erosion due to unexpected and/or uncertain flooding hazards. Nevertheless, Cyclone in coastal area increases salinity problem of agricultural field by flooding which causes agricultural productivity damage. Different categorized of farmers such as tenant, owner cum-tenant and owner tends to change their livelihood pattern. Many of them become unemployed, so that tenant people are diverted into other occupation such as rickshaw puller, hawker, garments worker, poultry worker, van driver, day labor etc. Owner cum-tenant shift to involve in various business. A number of peoples sometimes do not get any works then they involve to different crimes. At the same time, the price of essential commodities is rising with decreasing food availability. Food crisis occurs in the month of Katrik (October-November), Aswin (September to October), Choitra (March to April) and Boishakh (April to May) in the Northern part of Bangladesh. When the food crisis occurs, the villagers also use to change their food habit, villagers eats various types of vegetables and fruits such asLalshak (Red amaranth), Dhekishak (fern vegetables), Khalmiashak (Water Spinach), Palongshak (Spinach), Alu (Potato), Alushak (Potato leaf), Misty alu (Sweet potato), Patshak (Jute leaf), Bangi (Muskmelon), Tarmuj (Watermelon) etc (local name).

\section{Research Methods}

This qualitative research was carried out at Chilmari Upazila (Char Land Area) in the Kurigram district of Bangladesh. Most of peoples were depended on agroeconomy. It was located at the northern part of Bangladesh. However, natural hazard is a common issue in the aspects of geographical location.

This research work was carried out by the applying four types of methods which were adopted using different types of scholarly cited papers. It was carefully followed in the study area and kept more precision and accuracy for the Questionnaire Survey (Qs), Focus Group Discussion (FGD), Informal Dialogue (ID), Sitting Attitudinal Observation (SAOT) and Statistical Technique (ST).

The study was performed through structural questionnaire survey in the study area. It was consist of four parts (part one contained demographic information, part two contained perceptional information on climatic stress and agricultural activities, part three contained social crisis and part four livelihood pattern changing information). The questionnaire was administrated randomly [15] to serve our study purpose. The respondents were willingly agreed with interviewer persuasion and gave information politely. The information was recorded using feedback form and also written down in an extra note book which was preserved for the future coding and analysis.

Focus group discussion is a valuable technique to accumulate different opinion on a specific field of interest and to get clear concept on socioeconomic status and vulnerability [16]. It has an option to compare with another and get majority opinion in one thing. The FGD were performed within two groups, one was consisted of 21 members and another was contained 14 people. The 
participants were local people who are directly involved with agricultural activities and also fighting with natural hazards regularly. They were congenial to conversation with the interviewer and also agreed to give thematic information on climatic issues and its negative aspects of study area. The FGD was very much effective to enrich clear concept on climatic stress and livelihood changing pattern.

The informal dialogue (ID) is one of the suitable techniques to get lucid information from the local people. It is very much important which is done by behind of the people concern. It was contained instantly realistic view of the study purpose and objectives. Nevertheless, it was performed informally in various location and/or places like as on the street, local shop, tea stall and people gathering site in the community. This is confirmed to better output and inside view of the respondents.

Respondent's attitude test is the best approach to find out the real perception, core views, thinking and future plan. It is a new technique which was applied in this study. After the FGD, all participant were gossiping with each other then it was observed with the deep concentration by the sitting aside of them. They discussed, what was the feedback of FGD, actual problematic area and their future expectation?

The questionnaire was designed with using a number of likert-scale questions for getting clear concept on local environmental stress. It was confirmed real views on environmental hazards in the aspects of daily life style and pragmatic experiences in the study area. In categorical aspects, knowledge variability has been drawn from the participants. It was cleared to regional environmental aspects and its presents trends compare to previous condition. A number of aspects were included like as "Rainfall" "Average Temperature" "Flood Frequency" "Drought" "Wind Storm" "Average Humidity" "Groundwater Level" "River Discharge" "Food Security" and "Food Insecurity". It was stated with the scoring system in the reverse (positive and negative) order like as "agree"-5 " "Strongly agree"-4 "Either agree or disagree"-3 " disagree"-2 and "No comments"-1.

Correlation coefficient matrix was performed to know the relationship among the measured variables. This statistical analysis was carried out using statistical (MS Excel 2007 version and SPSS 11.5 version) windows package software. It is important to data coding, gathering and arrangement system for the statistical analysis [17]. This analysis has been revealed that, the better understanding feature and its coexisting controlling parameter.

\section{Results and Discussion}

\subsection{Socio-Economic Status and Existing Feature}

Socioeconomic status of a society indicates to the life style and professional achievement. It acts as primary indicator for one's to assess the life style and social acceptance. However, the studied population age was varied range from 12-67 years old. Most of the respondents (56 percent) were capable to write their name and address as a signatory level of education. It is divided into four groups depends on income level like as (US\$ 38.69) 3000(US\$ 64.48) 5000tk for one, (US\$ 64.48) 5000(US\$ 128.95) 10000tk for two, (US\$128.95) 10000(US\$193.43) 15000tk for three and (US\$193.43) 15000(US\$257.90) 20000tk for four. Most of the respondents are observed who (both male and female) were directly involved with agricultural activities. Agricultural activities are a main source of income in this community. A number of peoples were engaged in teaching profession at primary level education.

\subsection{Climatic Stress and Local Perception}

Climatic variables act as a controlling parameter to make balance in the atmospheric environment. Now, the discontinuation of climatic variables certainty is a concerning issues for the living organism in the aspects of survive. It is emerged from natural and anthropogenic induced hazards.

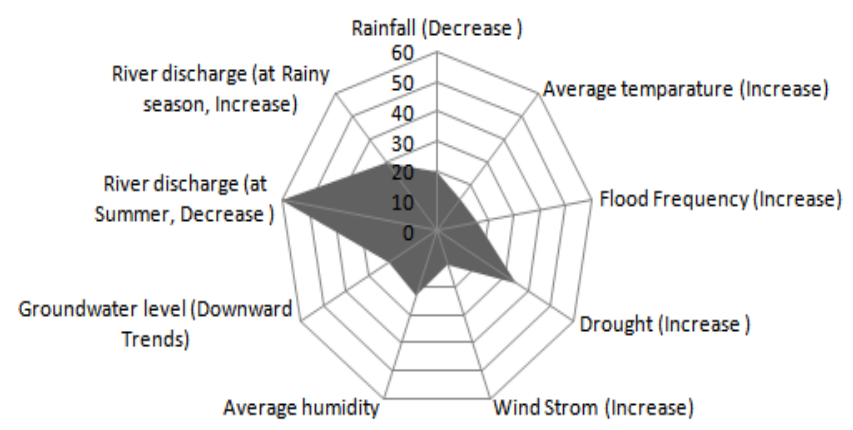

Figure 1. Local Perception and climatic variables (It is drawn primary concept on climatic variables and its negative aspects on agricultural sector. It was studied to find out the realistic point of environmental crisis and feasibility. Most of the respondents were known on this aspects and its probable theme on impacts at the local scale.)

A number of respondents reported that, overall climatic condition has been changed in the long term measure and existing evidence. According to previous experience 12 percent, 35 percent, 16 percent, 14 percent and 30 percent respondents were reported that, the average wind storm, drought, flood frequency, average temperature, river discharge (at rainy season) has increased and ground water level (35 percent) has decreased (Figure 1), but average rainfall (20 percent) and river discharge (at summer season, 60 percent) decreased (Figure 1) due to unexpected events. The average changing pattern of climatic variables will influence to the crop production rate and hydrological cycle [13] along with land degradation [18]. People perception and its long term impacts have been overlapped with the observational feature of the study area. Perceptional views of farmers on drought and secondary data of climatic variables indicate to resemblance in the aspects of extreme 
drought event [19]. Most of the people's livelihood pattern is being centralized around the agricultural activities. But climatic variables certainty and co-existing with the agricultural needs is very important to get high yield. Its discontinuation is negatively attributed to the average crop production rate and demand based needs fulfillment in the community people. Regarding with farmer perception, climatic variables (e.g. rainfall and temperature variability) are gradually changing and its negative impacts appear in their farming activities while a few number of resilient verities of crops are used to make balance but not more. Schlenker and Lobell, [20] reported that farmers have brought change in their farming activities against with more frequently occurring extreme events.

\subsection{Food Crisis and Natural Hazards}

Local people of the study area are continuously fighting with natural calamity for their present existence. It is negatively impacted on their socioeconomic status due to agricultural damage and production failure. Food security is directly indicated to nutritional status of human health which may relate to socioeconomic status [21]. Nevertheless, it was identified that, in particularly two types of natural hazards is directly made a linkage with the vulnerability and social crisis. Drought and Flooding hazards are frequently occurred in two times in a year. Soil moisture deficiency, duration and the total area of the affected region are considered to be important criteria for the drought severity measurement [19]. At the time of events, most of inhabitants are fallen in the worst condition which is associated with food shortage, shelter problem and domestic animal management. Regarding with respondents perception "....Actually we are victimized due to the flooding hazards in our char land because, at the time [Ashar (June to July), Srabon (July to August),Vadro (August to September)] of flooding hazards we did not get enough food and support to cope with this problem. Just we are instantly developed our adaptive capacity through bearing patients and fasting one or two times in a day. On the other hand, we are scared in night because any types of disaster may arise in this time like as death". A number of respondents has been reported that "Drought is one of our curse, because many of our agricultural crops spoil at that time due to overheating, burning, land exposure, fertility decrease, irrigation problem and ground water depletion, it is the main cause of food chain breakdown and poverty in our society. In addition, our nearest river has been lost its own current and water body owing to make a dam at the upstream point".

Regarding with farmer perception, February, March and April is critical time to adapt and ensure food availability at the household level (figure 2). Most of the family members remain under threat and risky position, which makes more vulnerable condition due to drought hazards. However, food shortage and local demand directly implies to high level of production rate at the time of hazards but on time it is not possible due to water scarcity (ground water level depletion, lack of rainfall, river dry out and scorching hot) and climatic variables instability. After a certain period of time, June, July and August are another time to occur flooding hazards regarding with farmer perception. Sometimes, it is occurred as catastrophic measure whereas it is not possible to predict of the flood frequency and magnitude using pragmatic experience due to climate change. At the time agricultural damage directly make a linkage with the adverse environmental condition and crop production failures which may negatively attributed to local food crisis and enhance poverty. Farmer perception only one factor, which is leading to alter of farming activities but extreme events like as flood and drought act as a key factor of food security. In addition, it is expected to formal credit and labor [14].

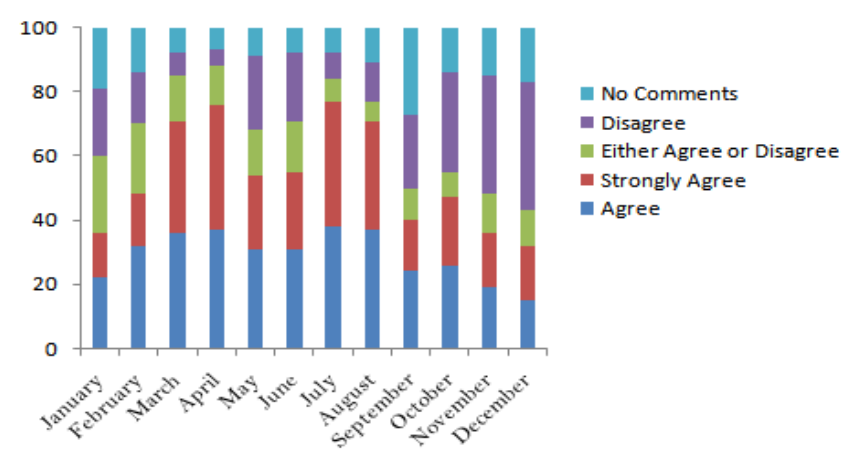

Figure 2. Shows the respondents opinion (in percentage) on natural hazards and food security (according to the respondents information, February, March and April is a very critical time for drought hazards and June, July and August is for flooding hazards. At this time, they do not able to lead their life style in a proper way).

\subsection{Land Use Pattern and Agricultural Activities}

Land use pattern of the study area was recorded whereas it was exposed as a char land at the Bramaputra river site. A major portion was used to agricultural activities after and before flooding hazards. A number of authors has emphasized on agricultural adaptations in the aspects of farming and land use management using and/or response of many climatic drivers [22-27]. Most of the land is used to different types of crop cultivation regarding with respondents views. But the production rate is varied from one place to another and crop to crop in a same site of the river bank. The cultivation item of crop was recorded in the char land like as rice, wheat, mustard, onion, garlic, pea, pumpkin, maize, sugarcane, millet, ladies finger, jute, tobacco, ground nut, potato and etc. However, a number of crops were not being so well production rate like as rice, mustard, sugarcane, garlic, banana and etc. In addition, a few respondents has been reported that a number of crops like as jute, maize, ground nut and wheat production rate is comparatively high due to the settlement of alluvial sediments after the flooding hazards. Sometimes, farmers apply of their won strategy (e.g. crop and water management, agriculture input, income diversification, migration and expenditure adjustment) to mitigate drought 
hazards and agro-based activities [19]. But long term crop diversification is a risk spreading matter by farming at the household level and in their field [28]. In some cases, uncertainly of the flooding hazards and heavy rainfall exposes as an unexpected catastrophic events. They reported that "we did not see again in our life because flood will be occurring but its discontinuation has been appeared for the last thirty years. That's why, we are scared about our life and its dynamism to future". It may be emerged from the long term climatic stress and its variable change.

\subsection{Why Food Insecure? Crop Production and Marketing System}

Food security and its abundance is a reflection of social security which is embodied on fundamental rights. In some cases, it may break chain of supply due to the interruption of proper management and resource unavailability.
According to the respondent's perception, "we (producer) cultivate different type's crop. But it is very important to look after farming activities until harvesting. On the other hand, now-a-days all sorts of agricultural accessories have to buy at high level of cost compare to selling our agricultural commodity to primary, secondary buyer and retailer". Consecutively, regarding with root level consumer "regularly we buy our necessary commodities and vegetables from the nearest market but I did not observe any remarkable price difference for a specific goods. So, it may not be depends on high production rate and availability. In my long term experience, we have to control at the price hiking step from primary buyer to retailer. It is so much than farmers selling at low cost". Have potential impacts on non-market and marketing system to secure food at the poor household level [29]. At the time of food crisis, it can have negative impacts on farmers and agricultural market price [29, 30].

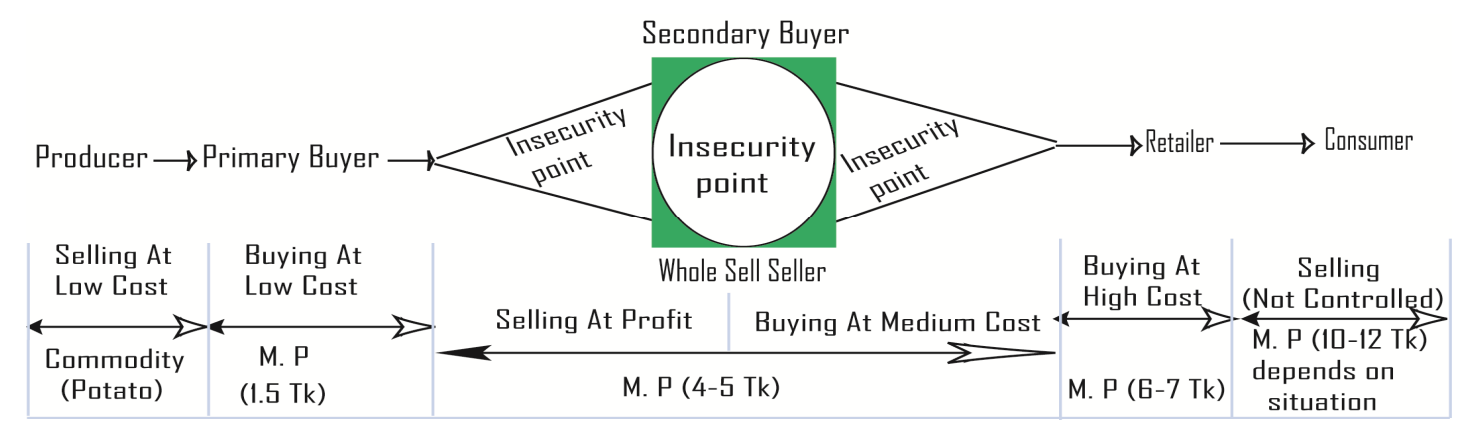

Figure 3. Shows commodity supply chain and market price [M.P, Tk (1USD=77.55 Tk, date: 24-06-2014)] trends (e.g. sometimes it acts as a great barrier to price control among the social people, food producers, vendors and retailers. Insecure point denoted that, market price instability and food crisis. In few cases, it may follow upward trend without any demarcation due to lack of proper monitoring and assessment).

Agricultural land reducing along with frequent natural disaster occurring at the study area is made food insecure in Bangladesh. Now-a-days food security is a great challenge in rural and disaster prone area which is indicated to local impacts, occupational stress and diversification. In the consequences of natural hazards, crop yielding rate is hampered and local respondents cited that "we are now facing climatic effects and food shortage problem". Further, frequently occurred extreme events (e.g. drought or heat wave) impede to proper crop production and its maintenance, it reduces ability to cope with food security, capital and productive assets and so on [31, 32]. On the other hand, a number of respondents reported that "After harvesting, we do not get actual price of our yielding crop". It may create supply chain impairment due to imbalance condition from producer to consumer (Figure 3). Ringler et al. [33] predicted that, $1.3 \%$ food availability would be decreased across Sub-Saharan Africa by middle of the century due to negative impacts of climate change and global food price hiking on key crops. Local consumer bought agricultural commodity at three to five times higher than first hand of buyer. In the aspects of expenditure, a number of smallholder farmers who are net buyers as they frequently purchase crop grain in hunger period and are compelled to sell at the harvesting time when prices are follow downward trends [34]. The government and support organization should take some steps in response of climatic effects which can have major impacts on regional agricultural markets and farmers. Climate change act as a key factor to control food price and it make food insecure who spend their most of the incomes to buy on food [35].

\subsection{Livelihood Change and Crisis}

Livelihood pattern is an indicator of socioeconomic structure and regional development in a specific area. It actually depends on social structure and resource availability which is act as a controlling parameter. But in some case, in presence of external factor (e.g. natural and human induced hazards and/or crisis) it may be changed from one point to another. According to respondents, most (90 percent) of people were depends on farming activities. However, at the time of hazards they do not able to crop cultivation due to uprising flooding and drought hazards. It is a critical point to find out the real feature of the study area crisis. Nevertheless, they do not get enough facility and/or support to lead their life at the crisis point. That's why, major part of respondents were reported that "At the time of flooding and drought hazards, we do not get job at the local place. So we migrate from our village to town to 
find out a job like as Rickshaw polar, day labor and in the Garments". A number of people were identified who were interested to business at the crisis moment at the small scale like as poultry farm, cloth, dry food, peanut selling and etc. Overall livelihood pattern has been changed and it may be expedited due to long term climate change. Climatic variables uncertainty has become a potential threat to char land population.

\subsection{Perceptional and Attitudinal Observation}

Perceptional views sometimes reveal real point of crisis which may explain individual experience and its probable scenario. The respondent's attitude has been demonstrated that, regional feature and the problematic site in a long term way of their life history. Local views and their practical evaluation indicate to the positive and negative aspects in between natural hazards and external initiatives to support (government and non-government) at the upcoming and recovery stage. A group of people were cited that "All sorts of initiatives are right but if we get instantly at the time of hazards occurring then it would be better to manage the situational condition. For this late support, a number of people do not get any way to cope with against with crisis". It is one of the negative aspects to ensure sustainable management approach. Regarding with respondents perception "Firstly we are human being then poor, we know everything, how to face and adapt at the time of hazard but financial crisis is our main problem, if get support then it will be great to survive against with all together". Pragmatic experience acts as a key parameter to learn something which is embodied on traditional life style in society.

\subsection{Food Security and Local Impact}

From the ancient period, subconsciously peoples are trying to secure their food. Most of the part in Bangladesh, Peoples are mainly depended on agro-economy. When agriculture production is gradually decreased, it's very tough to secure daily food habit in the community. Peoples are obliged to change their food habits due to crop yielding uncertainty. In the study area, most of the peoples were generally changed their traditional dietary and taking potato, maize instead of rice. People also take various vegetables like as chichinga (Snake gourd), dhekishak (Fern vegetable), lalshak (Red amaranth), alushak (Potato leaf) and etc as a usual food due to production failure and unavailability. However, for securing food, people also tends to change their livelihood patterns. Maximum people of the study area were farmer. Consequently, mainly three types of farmers were identified like as tenant, owner-cumtenant and owner [36]. Tenants are main victim of food crisis. They were frequently used agricultural land to cultivate through leasing system. In addition, flooding hazards, drought and/or heat wave act as key factor to loss of life, tends to loss of livelihood while it will affect to human health and infrastructure [37, 38]. However, the daily wages of tenant farmers were gone to follow downward trends. It was not sufficient to lead normal life style. Consequently, they have to change their present activities to better one and also migrated to nearest town, involving other business like as rickshaw puller, day labor, poultry farming and so on. On the other hand, Maximum respondents of them tend to go nearest town and/or Dhaka for more income as well as secure their foods. Unfortunately some of them involve various crimes like as hijacking, picketing, gambling, murder and so on. As a result, they lose their social status in the society. In addition, Owner cum tenant farmers reported that, they were involving in other business such as stock business of various grains, different shops, poultry business, hatchery business etc. But it is very difficult to adapt in a new income generating sector. They have been faced adverse situational and financial case. In the same way, owners were facing threat to overcome regional crisis which is evolved due to natural hazards. Sometimes their lands remain unproductive, and they willingly want to sell their land to make out the new way to survive. These diversifications are mainly occurs to maintain socioeconomic status and sustain in a minimum living standard.

\subsection{Correlation Coefficient Matrix}

The correlation coefficient revealed the better understanding among the variables dependency and independency characteristics. This correlation study was performed regarding with the respondent perception on climatic variables and its negative effects in the study area. It was found to be a significant positive correlation among the groundwater $(r=0.21 ; P=.01)$ and crop production rate $(r=0.19 ; P=0.01)$ considering with rainfall intensity. On the other hand, a significant negative correlation was observed both of flooding hazards $(r=-0.031 ; P=0.01)$ and drought $(r=-0.15 ; P=0.01)$ intensity with respect to crop yielding status. But, after flooding hazards it was showed a significant positive correlation with the production rate regarding with respondents information based on pragmatic experiences. In addition, a number of negative significant correlations were observed among the variables like temperature $(r=-0.19 ; P=0.01)$ and river discharge level $(r=-0.31 ; P=0.01)$ in relation to local impacts on agricultural activities.

\subsection{Recommended Thematic Outline}

The problematic site and its negative consequences has been drawn some outline in the study area. Most of peoples are affected due to unwanted natural hazards but it is very much important to control and/or manage the situation against with adverse environmental condition. In addition, compartmental researches step by step, need to find out some crucial points for coping mechanism build up, need to ensure fundamental rights at the time of natural hazards and further potential research (component wise) would be helpful to communicate within a short time among the 
victim (figure 4). It may be the outstanding way to get sustainability in a society against with natural and human induced hazards. Now-a-days food security is a great challenge in rural and disaster prone area which is indicated to local impacts, occupational stress and diversification. Now climate change is a critical point for the food security but it is possible to ensure food availability for the growing population using united efforts of policy and science. It should be needed to change dietary pattern on time resource scarcity $[39,40]$. At the local and global policy linked research along with institutional knowledge shearing attitude helps to accelerate make out a new way for the mitigation and adaptation approach [41].

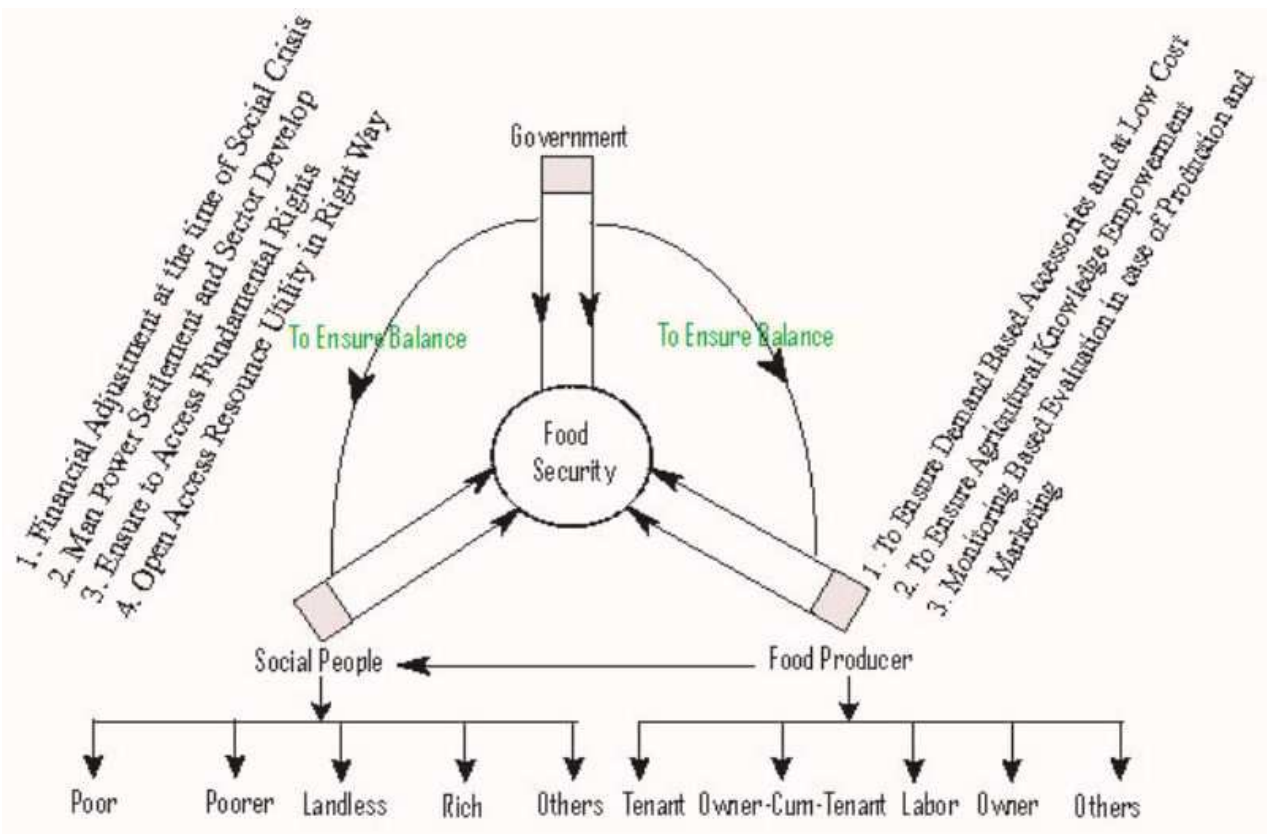

Figure 4. shows the real feature of agriculture depended food crisis in presence of natural hazards (flood and drought) and its probable outline to recover. It consists of perceptional views of local people and their expectation from government where does it may play a vital role to ensure community sustainability. It is noted that, food security goes on full fill the criteria, meet up government crisis to social people and food producer in the aspects of natural hazards.

\section{Conclusion}

People perception was observed owing to find out the real scenario along with adverse environmental circumstances in the study area. Local attitude was revealed towards worsen socioeconomic condition due to unexpected events (e.g. flood and drought). Regarding with respondents, climatic parameter frequently appeared with the changing pattern (showing discontinuation) in different times at the present age. However, People perception and its long term local impacts have been overlapped with the observational feature of the study area. It was found to be climatic parameter significantly negatively correlate with the crop production rate. Consequently, environmental condition and commodity marketing approach negatively attributed the local food crisis and/or insecurity. Also it was found to be majority of studied people tends to change their livelihood pattern from present farming activities to better one. Actually, climatic variables uncertainty identified as a potential threat for the char land people. In addition, compartmental researches step by step, need to find out some crucial points for coping mechanism build up, need to ensure fundamental rights at the time of natural hazards and further potential research (component wise) would be helpful to communicate within a short time among the victims.

\section{Acknowledgement}

The author acknowledged to the respondents who were willing to agree to give information regarding with research question. Author also acknowledged to the local people named Royal for his intensive support and cooperation.

\section{Conflict of Interest}

Author declares, it has no conflict of interest.

\section{References}

[1] M. Mirza, "Climate change, adaptation and adaptive governance in water sector in South Asia", Phys. Sci. Basis, pp. 1-19, 2007.

[2] Jarvis, C. Lau, S. Cook, E. Wollenberg, J. Hansen, O. Bonilla, and A. Challinor, "An integrated adaptation and mitigation framework for developing agricultural research: synergies and trade-offs", Exp. Agric., vol. 47, pp. 185-220, 2011. doi: $10.1017 /$ S0014479711000123. 
[3] P. Ericksen, P.Thornton, A. Notenbaert, L. Cramer, P. Jones, and M. Herrero, "Mapping hotspots of climate change and food insecurity in the global tropics", CCAFS Report No. 5. CGIAR Research Program on Climate Change, Agriculture and Food Security (CCAFS). Copenhagen, Denmark, 2011.

[4] CCAFS. Proposal for CGIAR Research Program 7: Climate Change, Agriculture and Food Security (CCAFS). Coordinating Unit of the CGIAR Research Program on Climate Change, Agriculture and Food Security, Copenhagen, Denmark;

http://ccafs.cgiar.org/sites/default/files/

ccafs_final_proposal_jan2011.pdf.

[5] IPCC Fourth Assessment Summary Report 2007, UNEP/UNDP.

[6] Asian Disaster Preparedness Centre, (ADPC) and Bangladesh Centre for Advanced Studies (BCAS), Draft Disaster Management Information Link Report, Comprehensive Disaster Management Programme (CDMP)", Component 5b, Ministry of Food and Disaster Management (MoFDM), Government of Peoples Republic of Bangladesh, Dhaka, Bangladesh 2008.

[7] Food and Agricultural Organization, "The State of Food Insecurity in the World 2001”, FAO, Rome, 2002.

[8] FAO, IFAD and WFP, "The State of Food Insecurity in the World 2013. The Multiple Dimensions of Food Security", FAO, Rome, 2013.

[9] T. Wheeler, and J. Von Braun, "Climate change impacts on global food security”, Science, vol. 341, pp. 508-513, 2013.

[10] O. Mertz, C. Mbow, J. Ostergaard Nielsen, A. Maiga, D. Diallo, A. Reenberg, A. Diouf, B. Barbier, I. Bouzou Moussa, M. Zorom, I. Ouattara, and D. Dabi, "Climate factors play a limited role for past adaptation strategies in West Africa”, Ecol. Soc., vol.15, pp. 25-39, 2010.

[11] H. Meinke, S.M. Howden, P.C. Struik, R. Nelson, D. Rodriguez, and S.C. Chapman, "Adaptation science for agriculture and natural resource management-urgency and theoretical basis", Curr. Opin. Environ. Sustain., vol. 1, pp. 69-76, 2009.

[12] I.M. Goklany, "Integrated strategies to reduce vulnerability and advance adaptation, mitigation, and sustainable development", Mitig. Adapt. Strat. Glob. Change, vol. 12, pp. $755-778,2007$.

[13] W.E. Easterling, P.K. Aggarwal, P. Batima, K.M. Brander, L. Erda, S.M. Howden, A. Kirilenko, J. Morton, J.F. Soussana, J. Schmidhuber, and F.N. Tubiello, "Food, fibre and forest products", In: Parry, M.L., O.F. Canziani, J.P. Palutikof, P.J. vander Linden and C.E. Hanson, (Eds.), Climate Change 2007: Impacts, Adaptation and Vulnerability. Contribution of Working Group II to the Fourth Assessment Report of the Intergovernmental Panel on Climate Change. Cambridge University Press, Cambridge, UK, pp. 273-313, 2007.

[14] H. Webber, T. Gaiser, and F. Ewert, "What role can crop models play in supporting climate change adaptation decisions to enhance food security in Sub-Saharan Africa?", Agricultural Systems, Xxx xxx-Xxx 2014 (in press).

[15] M. A. Rakib, and M. A. H. Bhuiyan, "Arsenic Contamination: Food Toxicity and Local Perception”, Int. J. Sci. Res. Env. Sci., vol. 2(1), pp. 1-7, 2014.
[16] R. Chambers, "The origins and practice of participatory rural appraisal", World Dev., vol. 22, pp. 953-69, 1994.

[17] J. Corbin, and A. Strauss, "Grounded theory research: procedures, cannons, and evaluative criteria", Qualitative Sociology, vol. 13(1), pp. 3-21, 1990.

[18] M.V.K. Sivakumar, and N. Ndiang'ui, "Climate and Land Degradation", Environmental Science and Engineering, Springer, Berlin, 2007.

[19] M. Ashraf, and J.K. Routray, "Perception and Understanding of Drought and Coping Strategies of Farming households in north-west Balochistan", International Journal of Disaster Risk Reduction, vol. 5, pp. 49-60, 2013.

[20] W. Schlenker, and D.B. Lobell, "Robust negative impacts of climate change on African agriculture", Environ. Res. Lett., vol. 5, pp. 1-8, 2010 .

[21] Bishwajit, R. Barmon, and S. Ghosh, "Reviewing the status of agricultural production in bangladesh from a food security perspective", Russian Journal of Agricultural and Socio-Economic Sciences, vol. 1(25), pp. 19, 2014.

[22] E. Bryan, T.T. Deressa, G.A. Gbetibouo, and C. Ringler, "Adaptation to climate change in Ethiopia and South Africa: options and constraints", Environ. Sci. Policy, vol. 12, pp. 413-426, 2009.

[23] E. Bryan, C. Ringler, B. Okoba, C. Roncoli, S. Silvestri, and M. Herrero, "Adapting agriculture to climate change in Kenya: household strategies and determinants", J. Environ. Manage., vol. 114, pp. 26-35, 2013.

[24] P. Tschakert, "Views from the vulnerable: understanding climatic and other stressors in the Sahel", Glob. Environ. Change, vol. 17, pp. 381-396, 2007.

[25] G.A. Gbetibouo, R.M. Hassan, and C. Ringler, "Modeling farmers' adaptation strategies for climate change and variability: the case of the Limpopo Basin, South Africa", Agric. Econ. Res. Policy Pract. South. Afr., vol. 49, pp. 217 $345,2010$.

[26] O. Mertz, C. Mbow, A. Reenberg, and A. Diouf, "Farmers' perceptions of climate change and agricultural adaptation strategies in rural Sahel", Environ. Manage., vol. 43, pp. 804-816, 2009.

[27] O. Mertz, C. Mbow, A. Reenberg, L. Genesio, E.F. Lambin, S. D'haen, M. Zorom, K. Rasmussen, D. Diallo, B. Barbier, I.B. Moussa, A. Diouf, J.O. Nielsen, and I. Sandholt, "Adaptation strategies and climate vulnerability in the Sudano-Sahelian region of West Africa", Atmos. Sci. Lett., vol. 12, pp. 104-108, 2011.

[28] W.N. Adger, S. Huq, K, Brown, D. Conway, and M. Hulme, "Adaptation to climate change in the developing world", Progress in Development studies, vol. 3, pp. 179-95, 2003.

[29] C.B. Barrett, "Food security and food assistance programs", In: B.L. Gardner, G.C. Rausser, (Eds.), Handbook of Agricultural Economics, Elsevier Science, Amsterdam, 2002

[30] A.Abdulai, C.B. Barrett, and P. Hazell, "Food Aid for Market Development in Sub-Saharan Africa", DSGD Discussion Paper \#5. International Food Policy Research Institute, Washington, DC, 2004. 
[31] P.K. Thornton, P.G. Jones, P.J. Ericksen, and A.J. Challinor, "Agriculture and food systems in sub-Saharan Africa in a 4 C+ world”, Philos. Trans. R. Soc. A., vol. 369, pp. 117- 136, 2011.

[32] Devereux, "Livelihood insecurity and social protection: a reemerging issue in rural development", Develop. Policy Rev., vol.19, pp. 507-519, 2001.

[33] Ringler, T. Zhu, X. Cai, J. Koo, and D. Wang, "How can African Agriculture Adapt to Climate Change: Climate Change Impacts on Food Security in Sub-Saharan Africa: Insights from Comprehensive Climate Change Modeling", International Food Policy Research Institute (IFPRI), 2011.

[34] M.E. Brown, "Markets, climate change, and food security in West Africa", Environ. Sci. Technol., vol. 43, pp. 8016 $8020,2009$.

[35] S. Vermeulen, R. Zougmore, E. Wollenberg, P. Thornton, G. Nelson, P. Kristjanson, J. Kinyangi, A. Jarvis, J. Hansen, A. Challinor, B. Campbell, and P. Aggarwal, "Climate change, agriculture and food security: a global partnership to link research and action for low-income agricultural producers and consumers", Current Opinion in Environmental Sustainability, vol. 4, pp. 128-133, 2012a.

[36] U. Habiba, R. Shaw, Y. Takeuchi, "Farmer's perception and adaptation practices to cope with drought: Perspectives from
Northwestern Bangladesh", Inte. J. of Disaster Risk Reduction,vol. 1,pp 72-84,2012

[37] S. Dercon, "Growth and shocks: evidence from rural Ethiopia", Journal of Development Economics, vol. 74 (2), pp. 309-329, 2004.

[38] M.R. Carter, P.D. Little, T. Mogues, and W. Negatu, "Poverty traps and natural disasters in Ethiopia and Honduras", World Development, vol. 35(5), pp. 835-856, 2007.

[39] H.C.J. Godfray, J. Pretty, S.M. Thomas, E.J. Warham, and J.R. Beddington "Linking policy on climate and food", Science, vol. 331, pp. 1013-1014, 2011.

[40] J.A. Foley, N. Ramankutty, K.A. Brauman, E.S. Cassidy, J.S. Gerber, M. Johnston, N.D. Mueller, C. O‘Connell, D.K. Ray, and P.C. West, et al. "Solutions for a cultivated planet", Nature, vol. 478, pp. 337-342, 2011, doi: 10.1038 /nature10452.

[41] S.J. Vermeulen, P.K. Aggarwal, A. Ainslie, C. Angelone, B.M. Campbell, A.J. Challinor, J.W. Hansen, J.S.I. Ingram, A. Jarvis, P. Kristjanson, C. Lau, G.C. Nelson, P.K. Thornton, and E. Wollenberg "Options for support to agriculture and food security under climate change", Environmental Science and Policy, vol. 15, pp. 136-144, 2012 b. 